\title{
National Parks-their Role in the Modern World
}

\author{
Kai Curry-LindahI
}

National parks are no luxury today, but an essential tool in every country, on every continent, and in the sea if man is to understand his environment and avert destruction. The author, who is Senior Adviser to the UN Environmental Programme, explains why the selection of the right areas is important, and what the criteria should be to avoid past mistakes.

Today-if man is to survive-he must plan his environment ecologically. Such planning must be world-wide, and national parks will certainly be part of it. In fact, the most significant results of biological field studies have emerged from work in national parks or equivalent reserves or other intact biocommunities.

Hitherto national parks have been regarded primarily as national show places, and the criteria for selecting suitable areas have been based on special features, such as spectacular landscape, rare geological sites, vegetation and/or fauna, or sites of historical events. In fact, many national parks were chosen to preserve natural curiosities. Such criteria are not wrong, but they emphasize single features rather than the whole natural scene-habitats, biomes, ecosystems-and such a limited approach may in the long run be dangerous; it can lead to unexpected surprises and the disappearance of what it was intended to preserve. No longer can we afford to base our actions on emotional romanticism. We have to face ecological realities, and these are very serious.

Today, however, the important role of national parks and equivalent reserves in a country's economy, land use and development, as well as in the fields of international conservation, research, education and recreation, is becoming increasingly recognised on all continents, and also by international organisations which are not directly involved in conservation.

One may ask whether it is possible to reconcile setting aside large areas for national parks with the conflict of land use, due to population and economic pressures and political aspirations. Parks are often regarded as unproductive. This is wrong. It is as vital to preserve habitats and ecosystems as it is to set aside areas for other human needs. This is the essence of ecological planning on a global scale.

Some people foresee a dim future for national parks in countries suffering from heavy overexploitation of their natural resources due to ecological ignorance and overpopulation. But we must learn from our mistakes when it comes to sound ecological planning and the formulation of long-term land use objectives. 


\section{Research and Education}

Because the importance of the environmental sciences, particularly ecology, is increasingly recognised, there is a growing demand for undisturbed research areas. This puts national parks in the focus of the scientific world. In ecological research natural areas are the only conceivable reference points for comparisons, enabling us to draw indisputable conclusions. They are among the few areas in the world where long-term investigations on quality and quantity, biomasses, energy turnover and conversion rates, evolution and speciation and so forth, can go on without human intervention. For educational purposes a system of national parks in every country, covering ecosystems in a wide variety of habitats and biomesgeological, hydrological, physiographical and ecological — would be of great value. Climax communities are particularly important because they show how diversity results in productive and healthy environments whereas monocultures are only viable if increasingly toxic pesticides and artificial fertilisers are applied.

In national parks, interpretation for visitors, to help them understand the environment and man's place in it as well as the value of national parks, should be a combination of at least six services; information, guiding, education, entertainment, propaganda and inspiration, as recommended by Edwards in 1965. In the 1968 African Convention on Conservation of Nature and Natural Resources an article on conservation education stipulates that the Contracting States 'shall make maximum use of the educational value of conservation areas'-i.e. national parks and equivalent reserves.

\section{Migration Routes}

There are far too many examples of serious mistakes in delineating national parks because those responsible knew nothing about the territorial requirements and migratory patterns of the wildlife, particularly how herbivorous species fit into the ecosystem. All too often migration patterns are drastically cut by the park boundaries, leaving outside the park areas that are necessary for the long-term survival of some species; and often interference by man has made these outside habitats unsuitable for seasonal use by migratory mammals. Such mistakes have jeopardised the purposes for which some important national parks were established. Watersheds and vegetation stability have also been upset by similar badly drawn boundaries. In future these factors will certainly play a much bigger role than hitherto in drawing up park boundaries, particularly in regard to mammal populations.

\section{Bird Flyways}

Alarmed by the progressive loss of marshes, bogs and other wetlands in Europe through drainage and so-called 'improvement' schemes, IUCN took the initiative in 1961 , in close cooperation with the International Council for Bird Preservation (ICBP) and the International Wildfowl Research Bureau (IWRB), to develop a pro- 
gramme on conservation and management of temperate marshes, bogs and other wetlands, to be called Project MAR. The purpose is to preserve, manage and utilise wisely the most important wetlands of Europe, Asia and Africa by a Convention on the Conservation of Wetlands of International Importance, especially as Wildfowl Habitat.

In selecting the areas (the so-called MAR List) to be covered by the Convention, ornithological criteria were used because comparative data were available, but the Convention is much wider and emphasises the fundamental ecological functions of wetlands as regulators of water regimes and as habitats supporting a characteristic flora and fauna, especially waterfowl. The Convention stresses the importance of aquatic habitats for swans, geese, ducks, waders and other waterfowl and wildfowl, all important species both for protein and as recreational resources. All need freshwater, brackish or marine areas for breeding, moulting, feeding, resting and wintering. Most are migratory and need not only undisturbed breeding quarters but feeding and wintering grounds along their flyways. This Convention is a step towards an intercontinental approach to preserving habitats in great need of protection. It will facilitate the management of waterfowl as an international resource of great value.

But there are other migratory birds than waterfowl. Passerine birds, many of which migrate on a broad front over seas and deserts, need protected areas for feeding and resting after crossing, for instance, the Caribbean Sea or the Gulf of Mexico, the Mediterranean or the Sahara, the South China Sea or the Bay of Bengal. Yet their points of arrival, particularly round the Mediterreanean, are regularly the scene of mass slaughter by trapping and shooting during both spring and autumn migrations, and rare and common species are killed indiscriminately. A network of protected areas is necessary and of international interest. Likewise some Sahara oases also function as feeding and resting stations, although in this case it appears that the birds, crossing on a broad front, find them more at random.

Migrating birds of prey often follow land contours in order to avoid open seas or large lakes, and then congregate in great numbers at certain sites, where they are obviously very vulnerable to human persecution. Hecatombs of raptors occur every year in such resting places in many parts of Central America, in the Bosphorus in Turkey, the Greek archipelago, Malta and Cyprus. In all these areas migratory birds should be protected at least during migration. A few already have this protection.

\section{Fish Migration Routes}

It is almost too late to preserve any major river system in its entirety; there would of course be many ecological advantages-hydrological, limnological, ichthyological-in doing so. In national park systems fish are often treated differently from terrestrial animals; it is difficult to understand why, for it is just as important to preserve fish in natural habitats as other vertebrates. Yet fish migration routes have often been cut or adversely affected by interference both inside and 
outside national parks. Ecologically it would certainly be immensely valuable if at least some river systems supporting migratory fish, both anadromous and sedentary freshwater species, could be preserved. They are important parts of the ecosystems.

\section{Submarine Habitats}

Submarine national parks are just as important as terrestrial reserves for science, education and recreation. Coming decades will undoubttedly see the establishment of many new ones, with tourism the initial driving factor. Experience of such parks and reserves in Florida, the Bahamas, the Caribbean Virgin Islands, Costa Rica, Kenya, Ceylon, Japan, Australia and many islands in the southern Pacific show not only their tremendous potential but also that they are easy to run, provided damaging activities, such as fish dynamiting, spear fishing, shell and coral collecting, are strictly controlled.

\section{Ethical Aspects}

Those who have had the opportunity to study closely mammals such as primates, carnivores, seals and whales, have been struck by their high degree of intelligence, developed social systems, and by their individual characters and personalities. These animals live meaningful lives both in their own communities and as a part of ecosystems, and the same is true of other species. All have an intrinsic right to exist, and in national parks they can do so. It is also primarily in national parks that man can discover (and shed) the many fallacies and misconceptions that have prevailed for generations.

Much public interest in and support for conservation is motivated by ethical beliefs. Many people get immense satisfaction from knowing that wild habitats and wild animals are protected even if they themselves may never see them.

\section{Wilderness and Strict Nature Reserves}

In national parks and equivalent reserves there should be a clear distinction between 'wilderness areas' and 'strict nature reserves'; in the former walkers can be allowed and only minimal facilities provided; the latter should be used only for scientific research.

The increased public demand for wilderness areas raises the problem of whether more existing wilderness areas should be made more accessible. Inaccessibility and remoteness are, of course, their best defence and the best guarantee for the continued undisturbed function of ecosystems. Once disturbed, many biocommunities and ecosystems may be destroyed for all time. Obviously wilderness areas can only be maintained if they are not overused. Strict nature reserves used exclusively for research are at least equally important and may turn out to be essential for human existence.

\section{A Global Network}

The world of tomorrow will fully realise the importance of intact ecosystems, not only as a kind of work place for scientists, but also for 
comparative studies with used areas. We need such comparisons so that governments, landscape planners and, in fact, society as a whole, can learn the lessons the intact ecosystems can teach us and draw conclusions on which to base their plans. Such large areas could, of course, be used as national parks, and where a representative ecosystem is preserved in the form of a national park, all other activities need not be excluded so long as these are not detrimental to the area preserved. Such areas will be selected by the World Heritage Trust, which is now in the form of a Convention, taken care of by UNESCO. In his 1971 message to Congress on the environment the President of the United States said,

The national park concept is based upon the recognition that certain areas of natural, historical, or cultural significance have such unique and outstanding characteristics that they must be treated as belonging to the nation as a whole, as part of the nation's heritage. It would be fitting by 1972 for the nations of the world to agree to the principle that there are certain areas of such unique worldwide value that they should be treated as part of the heritage of all mankind and accorded special recognition as a part of a World Heritage Trust. Such an arrangement would impose no limitations on the sovereignty of those nations which choose to participate, but would extend special international recognition to the areas which qualify, and would make available technical and other assistance where appropriate to assist in their protection and management. I believe that such an initiative can add a new dimension to international cooperation. Confronted with the pressures of population and development, and with the world's tremendously increased capacity for environmental modification, we must act together now to save for future generations the most outstanding natural areas as well as places of unique historical, archaeological, architectural, and cultural value to mankind.

\section{Integrity of National Parks}

In 1864, when the Yosemite Valley in California was transferred to the Federal Administration, Congress declared that 'some lands should be held in public ownership, perpetually, for other than material gain or richness'. One hundred and five years later, the 10th General Assembly of IUCN, meeting in New Delhi, adopted unanimously the following definition:

A National Park is a relatively large area (1) where one or several ecosystems are not materially altered by human exploitation and occupation, where plant and animal species, geomorphological sites and habitats are of special scientific, educative and recreative interest or which contains a natural landscape of great beauty; and (2) where the highest competent authority of the country has taken steps to prevent or to eliminate as soon as possible exploitation or occupation in the whole area to enforce effectively the respect of ecological, geomorphological or aesthetic features which have led to its establishment; and (3) where people are allowed to enter, under special conditions, for inspirational, educative, cultural and recreative purposes.

Hence, although the concept of national parks integrity has been in existence over 100 years, since the first national park was created, numerous governments have violated it by exploitation in national 
parks leading to serious destruction. As a Swede I regret to say that Sweden has in recent decades ravished more national parks and equivalent reserves than any other country. Her government, without any economic pressure, has initiated and exploited one national park and nature reserve after another, and the destruction continues despite protests from responsible national and international conservation organisations over the last thirty years. In European Conservation Year 1970, IUCN, ICBP and IWRB wrote independently to the Swedish Prime Minister, urging him to stop entirely an exploitation scheme in one national park and one bird sanctuary of international importance (on the MAR list). The government did not change its plans; it was forced by the parliament to modify them, but the environmental destruction will still be serious and demonstrates a total lack of conservation responsibility and vision for future needs. Flagrant cases of environmental misuse and violation of national parks, such as this one, show the imperative need for international pressure on a government. It should be obvious that national parks and equivalent reserves must be protected against all human exploitation of their natural resources and against all other derogation of their integrity.

In our stage of civilisation it is high time that all nations declared their acceptance of the principle of national parks integrity as a universal act of solidarity. Major modifications in national parks must be banned in the interest of humanity.

\section{Literature}

CURRY-LINDAHL, K. 1973. Projecting the future in the worldwide national parks movement. Second World Conference on National Parks, Yellowstone and Grand Teton National Parks, September 18-27, 1972. IUCN, Morges.

\section{Thailand's Wild Animal Trade}

Illegal trading in wildlife both internally and for export is both widespread and considerable in Thailand, according to a correspondent recently returned. There is an established trading route for wild animals from Thailand to Laos, via Singapore, Malaysia and Hong Kong, designed to circumvent the law. In the Weekend Market in Bangkok he saw some forty stalls selling both wild and tame animals (usually in cramped and often dirty conditions), including endangered species such as white-handed gibbon, and also otters, honey bears, leopard and golden cats, squirrels, macaque monkeys, turtles, terrapins, snakes and many birds. Many sales are to foreigners, especially of otters and gibbons. A dealer in Bangkok recently had on his premises four orang utans in small cages which could only have been smuggled into the country and could not legally be exported, as well as marbled cat, civets, douc langur, pig-tailed and stumptailed macaques, otters, binturong, loris, squirrels and mongoose; birds included crested serpent eagles, kites, many species of finch and painted guinea fowl; reptiles included pythons, green tree snakes and numerous terrapins; trade was with USA and Europe, and the USSR via the Netherlands. Another dealer was prepared to fulfil orders for a wide range of species including elephants, large cats and small primates. Protected species were no problem: 'matters could be arranged'. Conservationists, notably Dr Boonsong Lekagul and members of the Thailand Association for the Conservation of Wildlife, get little support from the Government. 


\title{
Black Rhinoceros in Zambia
}

\author{
W. F. H. Ansell
}

An assessment of the status of the black rhinoceros in Zambia, by W. F. H. Ansell, published in Oryx, December 1969, has been reprinted in Black Lechwe, journal of the Wildlife Conservation Society of Zambia, Volume XI No 2, with the following additional information.

\section{Kafue National Park and adjacent areas}

Rhinoceros continue to be seen fairly frequently both in the north and south of the national park, and are probably increasing gradually in numbers. They are evidently fairly well established in the area between the Nkala and Musa rivers as well as in the northern sector.

In 1971 R. D. Rohwer, then of Zambia Safaris Ltd, reported three males, two females, and a calf in some dense thickets west of the Munte/Mufumbwe confluence in the Kasonso-Busanga GMA, square 1425-B-1*; where he had frequently seen them or their fresh spoor. This is just north-west of the Kafue National Park. In 1969 I considered the species perhaps only sporadic from the Lushimba stream northwards, and it is not clear whether those reported by Rohwer represent a local extension of range in recent years, or whether a small population remained unnoticed there until 1971.

\section{Luangwa Valley}

Surveys carried out by the UN/FAO Luangwa Valley project, which ended in March 1973, showed that the estimates given in my 1969 paper were very much on the low side. The report of this project has not yet been completed, but the rhinoceros population in the valley GMAs is currently estimated at about 12,000 , with an absolute minimum of 4000 .

\section{North-Western Province}

A record overlooked in the 1969 paper is of a rhinoceros reported in September 1962 at Kasempa, between the Kaonde Hospital and the Nkenyauna stream. This is in square $1325-\mathrm{B}-4$, very close to the boma, and is the only definite record of a rhinoceros in the area, at least for very many years.

\section{Middle Zambezi, above the Kafue confluence}

Rhinoceros spoor was reported by Wildlife Guard G. Nkoma in August 1972 east of the Kariba road, in the vicinity of the Mbendele stream, 1628-B-3. Evidently a few remain in the area, though in my 1969 paper I did not rate their chances of survival very highly.

In May 1969 Dr E. K. Balon, then with the Central Fisheries Research Institute, reported seeing a rhinoceros on Chete Island in Lake Kariba (1727B-3). It is well known that elephant and impala survive on Chete, but this is the only report of rhinoceros there, and it may have been a single individual.

\section{Lavushi Manda National Park}

In 1970 a carrier employed by the ranger at Chiundaponde reported that he thought there must be at least six rhinoceros in Lavushi Manda, judging by

$* 1^{\circ} \times \frac{1}{4}^{\circ}$ locus, corresponding to the $1: 50,000$ map sheet 
the signs he saw when poaching there in 1969. A wildlife guard reported seeing one in 1971 just west of the north-western corner of the park. This was between the Lubweshi and Lupembashi streams, both tributaries of the Lumbatwa River. In July 1973 guards apprehended a poacher in the same place who had just killed a female rhinoceros. This was proof positive that the species survived in the area, though it came about in a most unfortunate manner. However, this cow had been accompanied by a bull, and a fair amount of spoor has also been found in the area

There has been no recent definite record within the Lavushi Manda National Park itself since the somewhat circumstantial report by the carrier in 1970 , but the outlook appears distinctly encouraging. I have myself always considered it possible that a few rhinoceros remain in the area.

\section{Sumbu National Park}

In the 1969 paper I doubted that any rhinoceros remained in the Sumbu Game Reserve, as it then was; like Lavushi it became a national park in 1972. However, in June 1969 Dr E. K. Balon reported seeing two at the edge of thick bush near the lower Lufubu River (Liendwe Valley). Unfortunately the photograph he took was lost, but subsequently wildlife guards have reported finding signs of rhinoceros in the area, so it is hoped a small population may remain. These further reports indicate that the species is continuing to hold its own in Zambia generally, and that in the Luangwa Valley it has to be regarded as common.

\section{Some Bird Books}

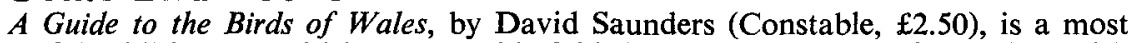
useful addition to British topographical bird guides. For each of the old Welsh counties, which fortunately still survive for naturalists as Watsonian vice-counties, he gives a general topographical and ecological summary, information about avifaunas, bird reports, local societies and important bird-watching sites, and a checklist of the birds.

Flight Identification of European Raptors (Poyser, Berkhamsted, Herts, f4.80), by R. F. Porter, Ian Willis, Steen Christensen and Bent Pors Nielsen, is a reprint of eight invaluable articles in British Birds on a most difficult aspect of the birdwatcher's art, but one in which real progress has been made in the past ten years. Each species is represented by a series of excellent drawings and black-and-white photographs (colour is much less useful here than for most birds), and there is a useful new chapter on the birds' legal status.

After 34 years it is good to see Watching Birds, James Fisher's fuse that ignited the great modern bird-watching explosion, in a new edition brought thoroughly up to date by Jim Flegg, who as Director of the British Trust for Ornithology, occupies the corresponding position to Fisher in 1940. (Poyser, Berkhamsted, Herts, £2.80).

Another standard field guide in a revised edition is Dr Boonsong's admirable Bird Guide of Thailand, in which he is now assisted with the text by Edward W. Cronin,

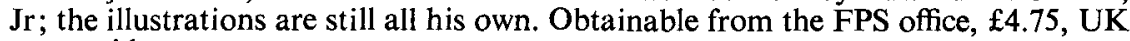
post paid.

Birds of the West Indies, by James Bond (Collins, £2.95), is now in its fourth edition, as befits a standard field guide. 